\title{
Sea Buckthorn Leaf L-quebrachitol Extract for Improved Glucose and Lipid Metabolism in Insulin Resistant HepG2 Cells
}

\author{
Yihan Mu, ${ }^{\text {a Cui Tao, }}$, Weiqiong Yuan, ${ }^{\mathrm{c}}$ and ZhaoLin Lv ${ }^{\mathrm{a}, \mathrm{d}, *}$ \\ L-quebrachitol is a natural monomethyl ether derivative of inositol, and it is \\ abundant in sea buckthorn leaves. In this study, the potential efficacy on \\ hepatic glucose, lipid metabolism disorder, and damaged pathway in vitro of \\ sea buckthorn leaf L-quebrachitol extract (SQE) and L-quebrachitol standard \\ (QS) was evaluated. The SQE and QS exhibited good inhibitory activity on a- \\ amylase, and the kinetic study revealed that their type of enzyme inhibition \\ was competitive inhibition in each case. Both QS and SQE increased the \\ glucose consumption and decreased the contents of total triglyceride (TG) and \\ non-esterified fatty acid (NEFA) in HepG2 cells displaying insulin resistance \\ (IR). In addition, QS and SQE attenuated the expression levels of G6Pase and \\ enhanced the expression of PPARa. These findings suggested that QS and \\ SQE contributed to the modulation of glucose and lipid metabolism, and they \\ might be a promising functional food additives and pharmaceuticals against \\ Type 2 diabetes mellitus (T2DM).
}

DOI: 10.15376/biores.17.1.527-542

Keywords: Sea buckthorn leaves; L-quebrachitol; Extract; Hypoglycemic; Insulin resistance; HepG2 cells

Contact information: a: College of Biological Sciences and Biotechnology, Beijing Forestry University, 100083, Beijing, China; b: China Meat Research Centre, 100068, Beijing, China; c: People's Government of Tuguiwula Town, Chahar Right Front Banner, 012200, Ulanqab, Inner Mongolia, China; d: Department of Beijing Key Laboratory of Forest Food Process and Safety, 100083, Beijing Forestry University, Beijing, China; *Corresponding author: zhaolinlv@126.com

\section{INTRODUCTION}

Diabetes mellitus, a metabolic disorder involving the disturbance of carbohydrate, protein, and fat metabolism, is a serious threat to the current and future health of people on Earth (Cao et al. 2019). Type 2 diabetes mellitus accounts for around $90 \%$ of all cases of diabetes and is characterized with hyperglycemia caused by insulin resistance (IR) (Hu et al. 2019a). Insulin resistance is a common pathophysiological basis in patients with several abnormalities, such as T2DM, hyperlipidemia, and obesity (Jing et al. 2018), which exhibits the manifestations of impairment of glucose utilization and decrease of insulin sensitivity (Hu et al. 2019b). The liver plays a key role in the metabolism of carbohydrates and fats, so hepatic insulin resistance is vital for the development of T2DM (Bechmann et al. 2012). Therefore, potential regulation of glucose and lipid metabolism in the liver may be an important pathway for the prevention and treatment of T2DM (Jing et al. 2018). Various drugs are used to treat diabetes, including insulin, $\alpha$-glycosidase inhibitors, sulfonylurea, and biguanide, which might have several obvious side effects and defects. The bioactive constituents from natural plants are widely favored and have been used to treat diabetes and its complications due to their efficacy and safety.

Sea buckthorn (Hippophae rhamnoides L.) is a spiny nitrogen-fixing deciduous 
shrub and is naturally distributed in Asia and Europe and cultivated in Asia, Europe, and the North America. It has the characteristics of cold resistance, drought resistance, and strong germination (Zielinska and Nowak 2017). Plants growing in harsh environments tend to accumulate more metabolites that are implicated in activation and reinforcement of defense mechanisms to cope with environmental stress (Yang et al. 2018). Therefore, sea buckthorn is not only widely employed for soil and water conservation and ecological restoration, but it also contains abundant nutrients and a variety of physiologically important active substances such as flavonoids, phenolic compounds, tocopherols (Khan et al. 2010). Compared with the berries, the sea buckthorn leaves have not been fully studied. The leaves are neglected and wasted due to the lack of application. It is worth noting that a recent study by the author's research team found that sea buckthorn leaves are rich in a derivative of inositol, L-quebrachitol $(59.73 \mathrm{mg} / 100 \mathrm{~g}$ dry leaves) (Tao et al. 2019).

L-quebrachitol (1L-2-O-methyl-chiro-inositol) is a natural monomethyl ether derivative of inositol. It was first isolated from quebracho bark in 1887 and purified from the same plant in 1906 (McCance and Lawrence 1933). Inositols are synthesized from glucose-6-phosphate and consist of nine isomeric forms, many of which can form methyl ether inositol derivatives (Michell 2008). These inositols and inositol derivatives are essential components of membrane phospholipids in animals and humans, wherein they play an important role in mediating cell signaling (Michell 2008). Inositols participate in insulin metabolic action, and the chiro-inositol levels are decreased in T2DM (Sleight et al. 2002; Larner et al. 2010). Previous research found that D-pinitol (3-O-methylchiroinositol), D-Chiro-inositol, and sequoyitol (5-O-methyl-myo-inositol) have effects on improving hyperglycemia (Shen et al. 2012; Gao et al. 2015). Therefore, it is necessary to identify additional inositol derivatives and to evaluate their therapeutic potentials. Lquebrachitol was illustrated to play an important role in the process of cell growth and intracellular signaling, and it can also effectively maintain osmotic pressure and treat gastric injury (De Olinda et al. 2008). Xue et al. (2015) found that sea buckthorn juice significantly improved glucose tolerance and the integrity of pancreatic tissue in type 2 diabetic $\mathrm{db} / \mathrm{db}$ mice, and they speculated that L-quebrachitol might have contributed to the effects observed. However, studies about L-quebrachitol comprehensive efficacy on hepatic glucose, lipid metabolism disorder, and damaged pathway in vitro have not been reported. Based on this situation, this context was aimed at evaluating the antidiabetic properties of L-quebrachitol and the effect of L-quebrachitol extract of sea buckthorn leaves on IR HepG2 cells.

\section{EXPERIMENTAL}

\section{Materials and Chemicals}

Dried sea buckthorn (Hippophae rhamnoides L. subsp. mongolica) leaves were supplied by Inner Mongolia Yuhangren High-Technology Industrial Co., Ltd. (Hohhot, China). The leaves were ground to a 20 -mesh powder and stored at $-20{ }^{\circ} \mathrm{C}$ in darkness before use. The sea buckthorn leaf L-quebrachitol extract (SQE) was prepared in two steps. First, it was extracted from sea buckthorn leaves through an aqueous solution, and then it was purified through a silica gel column.

Porcine pancreatic $\alpha$-amylase, acarbose, insulin, and rosiglitazone (RSG) were purchased from Sigma-Aldrich Chemical Co., Ltd. (St. Louis, MO, USA). Dimethyl 
sulfoxide (DMSO), 3,5-dinitrosalicylic acid (DNS), sodium potassium tartrate tetrahydrate, $\mathrm{NaH}_{2} \mathrm{PO}_{4} \cdot 12 \mathrm{H}_{2} \mathrm{O}, \mathrm{Na}_{2} \mathrm{HPO}_{4} \cdot 2 \mathrm{H}_{2} \mathrm{O}$, thiazolyl blue tetrazolium bromide (MTT), $\mathrm{NaCl}$, and $\mathrm{NaOH}$ were purchased from Shanghai Macklin Biochemical Co., Ltd. (Shanghai, China). L-quebrachitol standard (> 98\% purity) (QS) was purchased from Shanghai Anpel Scientific instrument Co., Ltd. (Shanghai, China). Glucose oxidaseperoxidase method kit, triglyceride (TG), nonesterified fatty acid (NEFA), assay kit, and total protein extraction kit were provided by Beijing Applygen Technologies Co., Ltd. (Beijing, China). All chemicals and solvents were analytical reagent grade or better.

Dulbecco's Modified Eagle's Medium (DMEM) and fetal bovine serum (FBS) were purchased from Gibico (Thermo Fisher Scientific, Grand Island, USA). Peroxisome proliferator activated receptor-alpha (PPAR $\alpha$, Abcam, Cambridge, UK, 1:500), glucose 6 phosphatase (G6Pase), and $\beta$-actin (ab8227) antibodies were purchased from Abcam Inc. (Cambridge, UK).

\section{GC $\times$ GC-TOF/MS}

The SQE sample was dissolved in pyridine. Then $0.4 \mathrm{~mL}$ of hexamethyl disilizane (HMDS) and $0.2 \mathrm{~mL}$ of trimethylchlorosilane (TMCS) were added and silylated at $20{ }^{\circ} \mathrm{C}$ for $30 \mathrm{~min}$. Target compounds were collected by centrifugation for $10 \mathrm{~min}$ at $8000 \times \mathrm{g}$, the supernatant was analyzed by GC×GC-TOF/MS. The GC $\times$ GC-TOF/MS was carried out using an Agilent 7980B-5977AMSD gas chromatography-mass spectrometer (GC/MS) (Palo Alto, CA, USA) incorporating a Hexin 0610 time-of-flight mass spectrometer (Guangzhou, China). The first dimension was a SR-5MS capillary column $(30 \mathrm{~m} \times 0.25$ $\mathrm{mm} \times 0.25 \mu \mathrm{m}$; Agilent, America) and the second dimension was a DB-17MS capillary column $\left(1.295 \mathrm{~m} \times 0.18 \mathrm{~mm} \times 0.18 \mu \mathrm{m}\right.$; Agilent, America). The $\mathrm{GC}$ was held at $180{ }^{\circ} \mathrm{C}$ for $3 \mathrm{~min}$ and then raised at $5{ }^{\circ} \mathrm{C} / \mathrm{min}$ to $280{ }^{\circ} \mathrm{C}$ and held at this temperature for a further $8 \mathrm{~min}$. The carrier gas was He supplied at $1 \mathrm{~mL} / \mathrm{min}$. Solid-State Modulator (SSM 1800) (JandX Technologies, Shenzhen, China) enabled the comprehensive two-dimensional separations. The TOF interface and ion source temperatures were set at 260 and $200{ }^{\circ} \mathrm{C}$, with an electron energy of $70 \mathrm{eV}$. The mass spectra were analyzed in the range of 50 to 400 atom mass units (amu). The target was identified by comparing the retention times of the sample peaks with quebrachitol standard and the results of mass spectral library searches (NIST14 library, Shimadzu, Kyoto, Japan). The target contents were expressed as $\mathrm{mg} / 100 \mathrm{~g}$ dry leaves based on the standard curve line of the quebrachitol standard.

\section{a-Amylase Inhibitory Activity of L-Quebrachitol}

$\alpha$-Amylase inhibitory activity study

The inhibition assay with the $\alpha$-amylase was performed with slight modifications of a previously reported method (Kwon et al. 2008). Ca. $250 \mu \mathrm{L}$ of $\alpha$-enzyme solution (5 $\mathrm{U} / \mathrm{mL}$ in $20 \mathrm{mM}$ phosphate buffer containing $6.7 \mathrm{mM} \mathrm{NaCl}, \mathrm{pH} 6.9$ ) was incubated at 37 ${ }^{\circ} \mathrm{C}$ for $5 \mathrm{~min}$ with different concentrations $(0.25,0.5,1,1.5,2,3$, and $4 \mathrm{mg} / \mathrm{mL}, 0.25 \mathrm{~mL})$ of the tested compounds. $\mathrm{Ca} .0 .25 \mathrm{~mL}$ of the buffer was used as the blank control. Then, $0.5 \mathrm{~mL}$ of the starch solution (the starch solution was stirred at $90{ }^{\circ} \mathrm{C}$ for $20 \mathrm{~min}$ before use, $10 \mathrm{mg} / \mathrm{mL}$ ) was added to the mixture. After the mixture reacted for additional $5 \mathrm{~min}$, $1 \mathrm{~mL}$ of DNS reagent ( $96 \mathrm{mM}$ DNS with $30 \%$ sodium potassium tartrate in $2 \mathrm{~N} \mathrm{NaOH}$ ) was added and the mixture system was incubated at $100{ }^{\circ} \mathrm{C}$ for $8 \mathrm{~min}$. Each reaction mixture was diluted by adding $8 \mathrm{~mL}$ of distilled water and the absorbance was measured at $765 \mathrm{~nm}$ (UV-1800, UV Spectrophotometer, Shimadzu, Japan). Acarbose was used as a positive reference equivalent, and the enzyme inhibition activity was calculated as follows: 


$$
\text { Inhibition }(\%)=\left(O D_{\text {control }}-O D_{\text {sample }}\right) / O D_{\text {control }} \times 100 \%
$$

The concentration required to inhibit $50 \%$ activity of the enzyme ( $\mathrm{IC}_{50}$ ) was calculated by regression analysis.

Detailed kinetics analysis of $\alpha$-amylase inhibition by quebrachitol

To determine the inhibition mechanism, $\alpha$-amylase inhibition by QS and SQE was evaluated by monitoring the effects of two starch concentrations $(10,25 \mathrm{mg} / \mathrm{mL})$ via Dixon plot. The test concentrations of QS were 0.002, 0.004, 0.008, 0.02, and $0.04 \mathrm{mg} / \mathrm{mL}$, and the test concentration of SQE were $0.1,0.5,1.0,5.0$, and $10.0 \mathrm{mg} / \mathrm{mL}$. Inhibition constants $\left(K_{\mathrm{i}}\right)$ were determined by interpretation of Dixon plots, where the value on the $\mathrm{x}$-axis represents $K_{\mathrm{i}}$ (Dixon 1953).

Lineweaver-Burk (LB) and Dixon plots were used to determine the kinetic mechanisms of $\alpha$-amylase inhibition by QS and SQE, and the results were complementarily obtained by the two plots. The $\alpha$-amylase inhibitions due to QS $(0.04$ and $0.004 \mathrm{mg} / \mathrm{mL})$ and SQE $(0.1$ and $1 \mathrm{mg} / \mathrm{mL})$ were evaluated by monitoring the changes of different concentrations of the starch solutions $(5,10,15,20,25 \mathrm{mg} / \mathrm{mL})$, and the test method was the same as above. The Michaelis constant $\left(K_{\mathrm{m}}\right)$ and the maximum reaction velocity ( $\left.V_{\max }\right)$ at different concentration of the inhibitor can be obtained by following double reciprocal method (LB equation), and the type of enzyme inhibition was determined by interpretation of the LB plots (Lineweaver and Burk 1934). The Dixon equation was applied to calculate inhibition constant $\left(K_{\mathrm{i}}\right)$ :

$$
1 / v=1 / V_{\max }+K_{\mathrm{m}} / V_{\max } \times 1 / s
$$

where $v$ is initial reaction velocity, $V_{\max }$ is the maximum initial reaction velocity, $K_{\mathrm{m}}$ is Michaelis constant, $s$ is the concentration of the starch.

\section{Regulation of Glucose and Lipid Metabolism Based on Insulin-Resistant (IR) Liver Cancer HepG2 Cells Model \\ Cell culture}

Human liver hepatocellular carcinoma cells (HepG2) were obtained from China Three Gorges University (Chongqing, China) and cultured in DMEM supplemented with $10 \%$ FBS, penicillin $(100 \mathrm{U} / \mathrm{mL})$, and streptomycin $(0.1 \mathrm{mg} / \mathrm{mL})$ at $37{ }^{\circ} \mathrm{C}$ in a humidified atmosphere of $5 \% \mathrm{CO}_{2}$. The normally cultured HepG2 cell lines in log phase were used for subsequent experiments.

\section{Cell viability assay}

The HepG2 cell viability activity was evaluated using an MTT assay according to (Hu et al. 2019a). The HepG2 cells were seeded in 96-well plates at $5 \times 10^{4}$ cells/well (100 $\mu \mathrm{L})$ and cultured overnight. Then different concentrations of samples $(0.5,1.0,2.0,4.0$ $\mathrm{mg} / \mathrm{mL}$, diluted in DMEM) were added to the cells to a total volume $200 \mu \mathrm{L} / \mathrm{well}$, and the cells were cultured at $37{ }^{\circ} \mathrm{C}$ for $12 \mathrm{~h}$ and $24 \mathrm{~h}$, respectively. The control cells were treated with DMEM. After incubation, $20 \mu \mathrm{L}$ MTT $(5 \mathrm{mg} / \mathrm{mL})$ was added to each well and the cells were incubated at $37{ }^{\circ} \mathrm{C}$ for $3 \mathrm{~h}$. Then, MTT solution was discarded and $150 \mu \mathrm{L}$ of DMSO was added to dissolve the MTT-formazan crystals. The absorbance of each well was measured at $490 \mathrm{~nm}$ by Multiskan Spectrum (DNM-9602, Perlong Scientific, China). The relative cell viability was calculated as follows: 


$$
\operatorname{Viability}(\%)=\left(O D_{\text {sample }}-O D_{\text {blank }}\right) /\left(O D_{\text {control }}-O D_{\text {blank }}\right) \times 100 \%
$$

Establishment of IR-HepG2 cells model

The establishment of an IR HepG2 cells model was introduced according to the reported method (Chen et al. 2019) with slight modifications. The HepG2 cells were firstly seeded in 96-well plates at $5 \times 10^{4}$ cells/well $(100 \mu \mathrm{L} /$ well $)$ concentration and cultured for 24 h. After complete adherence of cells, HepG2 cells were cultured in serum-free highglucose DMEM for $12 \mathrm{~h}$. Then $200 \mu \mathrm{L}$ of insulin solution $\left(10^{-6} \mathrm{~mol} / \mathrm{L}\right)$ was introduced and cultured at $37^{\circ} \mathrm{C}$ for $24 \mathrm{~h}$. Then the IR-HepG2 cells model had already been established. The HepG2 cells were incubated in high-glucose DMEM with $10 \% \mathrm{FBS}$ at $37{ }^{\circ} \mathrm{C}$ as a negative control.

\section{Glucose consumption assay}

Glucose consumption assay was performed following by establishing the IRHepG2 cells model. Samples at different concentrations $(0.25,0.5,1.0$, and $1.5 \mathrm{mg} / \mathrm{mL})$ were used to treat the IR-induced HepG2 cell models, and the RSG $(0.1 \mathrm{mg} / \mathrm{mL})$ was used as a positive control. After 12 and $24 \mathrm{~h}$ of incubation, glucose assay kit (glucose oxidase method) was employed to assay glucose content in culture supernatant.

\section{Intracellular TG and FFA quantification}

The IR-HepG2 cells was treated with $1.0 \mathrm{mg} / \mathrm{mL}$ of samples, and the RSG $(0.1$ $\mathrm{mg} / \mathrm{mL}$ ) was employed as a positive control. After incubating $24 \mathrm{~h}$, cells were washed with PBS twice and lysed with $1 \%$ of Triton X-100 for 30 min on ice. The protein contents were measured by a BCA protein assay kit. The content of TG was tested using a TG test kit, and the levels of NEFA in cells were determined by the NEFA quantitation kit according to the manufacturer's instructions.

\section{Western Blotting}

After $24 \mathrm{~h}$ incubation of the IR-HepG cells treated with $1.0 \mathrm{mg} / \mathrm{mL}$ samples, the cells were washed three times with ice-cold PBS and recollected, then lysed with sample buffer (containing $1 \mathrm{mM}$ PMSF) on ice. After being homogenized on ice for $30 \mathrm{~min}$, the samples were centrifuged at $12,000 \mathrm{r} / \mathrm{min}$ for $5 \mathrm{~min}$ at $4{ }^{\circ} \mathrm{C}$, and the supernatants were collected for Western blot analysis. The protein concentration was determined by the BCA method. Equal amounts of total proteins were separated by sodium dodecyl sulfate (10\% or $12 \%$ ) and polyacrylamide gel electrophoresis (SDS-PAGE), then transferred to a polyvinylidene difluoride (PVDF) membrane. Membranes were blocked by being completely immersed in 3\% BSA-TBST (Tris-Buffered Saline with Tween 20) for 30 min at room temperature. Then the PVDF membranes was incubated and shaken overnight with primary antibodies at $4{ }^{\circ} \mathrm{C}$. After washing with $1 \times$ TBST three times, the membrane was incubated with the corresponding secondary antibodies for another $1 \mathrm{~h}$ at room temperature. Then the membrane was washed with 1×TBST three times, and the bands were revealed using ECL reagent and detected by the ChemiDoc MP Imaging System (Bio$\mathrm{Rad}$, California, USA). The levels of protein were normalized to $\beta$-actin expression.

\section{Statistical Analysis}

The experimental data were reported as means \pm standard deviations (SD). All the data were submitted to analysis of variance by ANOVA at a significance level of $\mathrm{P}<0.05$ using SPSS 20.0 (IBM, Armonk, NY, USA). 


\section{RESULTS AND DISCUSSION}

\section{Chemical Composition of SQE}

In order to identify the actual content of L-quebrachitol and all chemical composition in SQE, the GCXGC-TOF/MS measurement was used in this study. The results are exhibited in Table 1 and Fig. 1. Previous research reported that the comprehensive two-dimensional $\mathrm{GC} \times \mathrm{GC}$ technology is prominent in the achievement of a near-complete characterization of the sample due to its high sensitivity and high resolution (Wu et al. 2020). The actual content of L-quebrachitol in SQE was $5.18 \mathrm{mg} / \mathrm{g}$, which showed that the leaves of sea buckthorn were rich in L-quebrachitol. Tao et al. (2019) found that the content of L-quebrachitol in sea buckthorn leaves $(59.73 \mathrm{mg} / \mathrm{g}$ dry leaves) was higher than that of sea buckthorn pulp $(2.19 \mathrm{mg} / \mathrm{g}$ fresh pulp) and seeds $(0.39 \mathrm{mg} / \mathrm{g}$ fresh seeds). These all indicated that sea buckthorn leaf resources could be used as a sufficient source of L-quebrachitol. In addition to L-quebrachitol, seven monosaccharides in SQE were identified. The reason for the monosaccharides' residues in SQE as impurities might be due to the similar properties between L-quebrachitol and monosaccharides, both L-quebrachitol and monosaccharides are highly polar compounds. In the separation process of the silica gel column, the monosaccharide and the quebrachitol were difficult to separate completely, and the elution process was overlapped. The monosaccharides were eluted together to cause impurity interference.

Table 1. The Composition of Compounds in SQE

\begin{tabular}{|c|c|c|c|c|c|c|}
\hline NO. & Compounds & $\begin{array}{c}\text { Positive } \\
\text { Match }\end{array}$ & $\begin{array}{c}\text { Negative } \\
\text { Match }\end{array}$ & RI & $\begin{array}{c}\text { Chemical } \\
\text { Formula }\end{array}$ & $\begin{array}{c}\text { Content } \\
\text { (mg/g) }\end{array}$ \\
\hline 1 & D-Ribofuranose & 694 & 682 & 1641 & $\mathrm{C}_{5} \mathrm{H}_{10} \mathrm{O}_{5}$ & 0.17 \\
\hline 2 & D-Tagatofuranose & 756 & 797 & 1813 & $\mathrm{C}_{6} \mathrm{H}_{12} \mathrm{O}_{6}$ & 0.32 \\
\hline 3 & D-Lyxose & 758 & 769 & 1651 & $\mathrm{C}_{5} \mathrm{H}_{10} \mathrm{O}_{5}$ & 0.23 \\
\hline 4 & L-Quebrachitol & 855 & 855 & 1814 & $\mathrm{C}_{7} \mathrm{H}_{14} \mathrm{O}_{6}$ & 5.18 \\
\hline 5 & D-Glucose & 859 & 895 & 2037 & $\mathrm{C}_{6} \mathrm{H}_{12} \mathrm{O}_{6}$ & 0.74 \\
\hline 6 & D-Galactose & 692 & 692 & 1876 & $\mathrm{C}_{6} \mathrm{H}_{12} \mathrm{O}_{6}$ & 0.05 \\
\hline 7 & D-Mannose & 862 & 892 & 1844 & $\mathrm{C}_{6} \mathrm{H}_{12} \mathrm{O}_{6}$ & 0.89 \\
\hline 8 & L-Rhamnose & 649 & 649 & 1657 & $\mathrm{C}_{6} \mathrm{H}_{12} \mathrm{O}_{5}$ & 0.05 \\
\hline
\end{tabular}

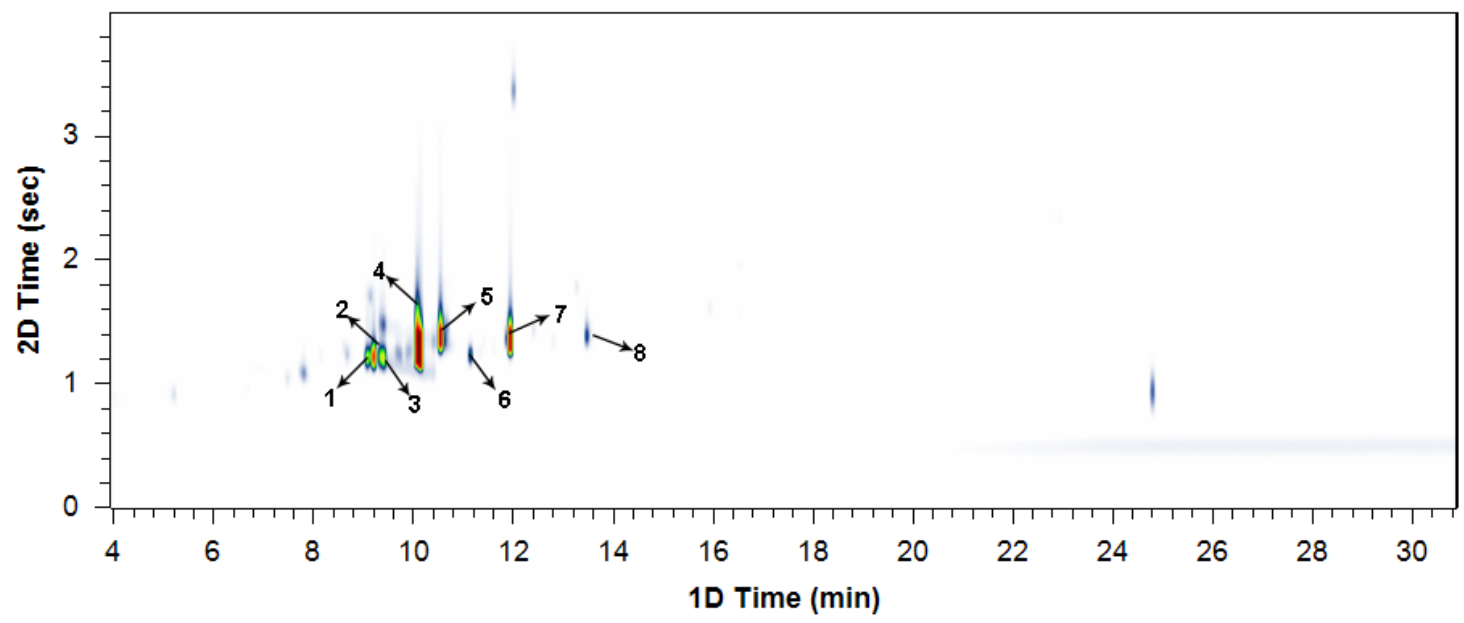

Fig. 1. GC×GC-TOF/MS chromatogram of $S Q E$ 


\section{a-Amylase Inhibitory Activity}

Inhibitory effect of L-quebrachitol against $\alpha$-amylase

$\alpha$-Amylase is an enzyme that affects the utilization of carbohydrate as an energy source, and it plays important roles in the hydrolysis of starch. Therefore, inhibiting the activity of $\alpha$-amylase can effectively delay the absorption of glucose and control the postprandial glucose levels of T2DM (Ayyash et al. 2018). The $\alpha$-amylase inhibitory activities of QS and SQE are shown in Table 2. The IC 50 and $K_{\mathrm{i}}$ of QS $\left(\mathrm{IC}_{50}=0.604 \mathrm{mg} / \mathrm{mL}\right.$, $\left.K_{\mathrm{i}}=0.014 \mathrm{mg} / \mathrm{mL}\right)$ were lower than $\mathrm{SQE}\left(\mathrm{IC}_{50}=2.407 \mathrm{mg} / \mathrm{mL}, K_{\mathrm{i}}=5.524 \mathrm{mg} / \mathrm{mL}\right)$. Parameter $K_{\mathrm{i}}$ is the inhibitor constant of the inhibitor, which indicates the degree of affinity of the inhibitor with the enzyme, and reflects the inhibitory ability of the inhibitor to the target enzyme. The smaller the $K_{\mathrm{i}}$ value, the more favorable is the inhibitor's inhibitory effect on the enzyme.

The results showed that the inhibitory ability of QS on $\alpha$-amylase was stronger than that of SQE, but weaker than the positive control RSG with an $\mathrm{IC}_{50}$ value of $0.058 \mathrm{mg} / \mathrm{mL}$. Lo Piparo et al. (2008) reported that the inhibitory effect of biologically active substances on $\alpha$-amylase partially depends on the formation of hydrogen bonds between the hydroxyl groups of chemical compound and amino acid residues in the active site of a-amylase. It can be inferred that the inhibitory activity of quebrachitol is related to the hydroxyl groups contained in its structure.

Table 2. Detailed Kinetics of QS and SQE

\begin{tabular}{|c|c|c|c|c|c|}
\hline & \multicolumn{5}{|c|}{ Inhibitor } \\
\hline & \multicolumn{2}{|c|}{ QS } & \multicolumn{2}{|c|}{ SQE } & Acarbose \\
\hline $\begin{array}{l}\text { Concentration } \\
(\mathrm{mg} / \mathrm{mL})\end{array}$ & 0.004 & 0.04 & 0.1 & 1 & - \\
\hline$K_{m}(\mathrm{mg} / \mathrm{mL})$ & $10.833 \pm 0.035$ & $17.462 \pm 0.097$ & $12.5 \pm 0.327$ & $15.676 \pm 0.164$ & - \\
\hline$V_{\max }(\mathrm{mM} / \min )$ & $0.175 \pm 0.067$ & $0.185 \pm 0.009$ & $0.202 \pm 0.006$ & $0.202 \pm 0.014$ & - \\
\hline Inhibition Type & \multicolumn{2}{|c|}{ Competitive } & \multicolumn{2}{|c|}{ Competitive } & - \\
\hline$K_{\mathrm{i}}(\mathrm{mg} / \mathrm{mL})$ & \multicolumn{2}{|c|}{$0.014 \pm 0.003$} & \multicolumn{2}{|c|}{$5.524 \pm 0.048$} & - \\
\hline $\mathrm{IC}_{50}(\mathrm{mg} / \mathrm{mL})$ & \multicolumn{2}{|c|}{$0.604 \pm 0.054^{b}$} & \multicolumn{2}{|c|}{$2.407 \pm 0.023^{c}$} & $\begin{array}{l}0.058 \pm \\
0.008^{a}\end{array}$ \\
\hline
\end{tabular}

Each value is a mean of duplicate analysis \pm standard deviation. Different letters in the same row represent significantly different mean values $(P<0.05)$. - : Values not analysed

\section{Kinetics of inhibition of $\alpha$-amylase by quebrachitol}

The double-reciprocal LB plots and Dixon plots of $\alpha$-amylase inhibition in the presence of QS and SQE are presented in Fig. 2A to D. The LB plots intersected very near the $y$ axis. The $K_{\mathrm{m}}$ value increases, and the $V_{\max }$ value remains constant as the inhibitor concentration increases (Lineweaver and Burk 1934). These results were correlated with the classical pattern of competitive inhibition. Therefore, it could be preliminarily inferred that the inhibition of $\alpha$-amylase by the QS and SQE were all competitive inhibition with $K_{\mathrm{i}}$ values of $0.014,5.524$, respectively. These findings indicated that the structure of the inhibitor was similar to that of the enzyme substrate, and the inhibitor could compete with the substrate for the enzyme active site, reducing the affinity between the enzyme and the substrate, thereby showing a decrease in enzyme activity. 


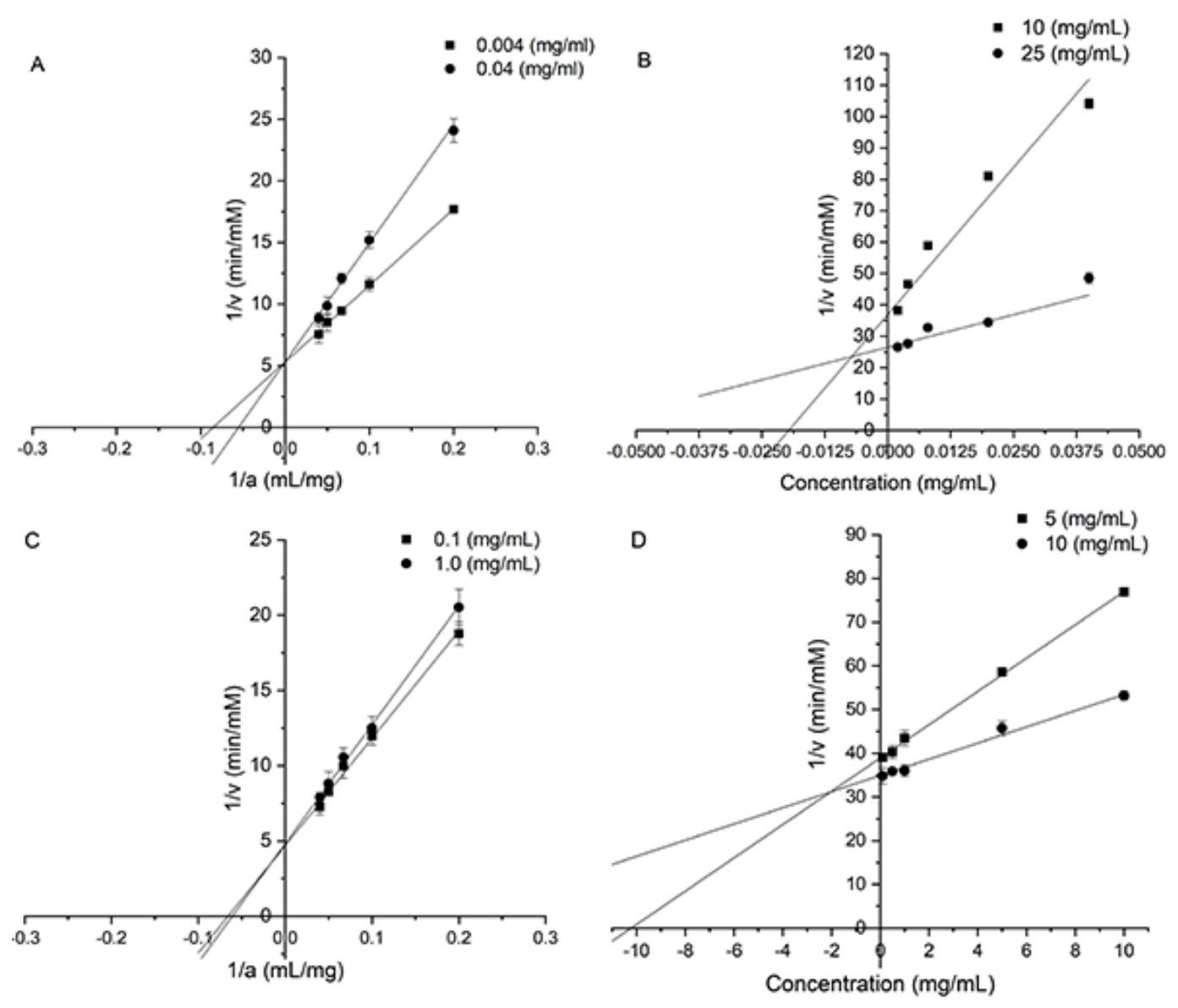

Fig. 2. (A) Lineweaver-Burk plot for $\alpha$-amylase inhibition by QS; (B) Dixon plots of $\alpha$-amylase inhibition by QS; (C) Lineweaver-Burk plot for $\alpha$-amylase inhibition by SQE; (D) Dixon plots of $\alpha$ amylase inhibition by SQE

\section{Influence of L-Quebrachitol on Cell Viability in HepG2 Cells and IR-HepG2 Cells}

The HepG2 cells are a hepatic embryonic tumor cell line derived from human liver cancer tissues (Cordero-Herrera et al. 2014). They show many characteristics of genotypes of normal human liver hepatocytes, and their biological activities are very similar to those of normal hepatocytes (Wang et al. 2020). In addition, hepatocytes play an important role in regulating glucose concentration (Aravinthan et al. 2015). Therefore, HepG2 cells are considered as the ideal model system for exploring human liver metabolism in vitro. In this study, the authors evaluated the cytotoxicity effects of QS and SQE on HepG2 cells firstly after 12 and $24 \mathrm{~h}$ treatment by MTT assay. The drug could be regarded as having no significant cytotoxicity on cell growth when the cell viability is above $80 \%$ (Yao et al. 2018). As shown in Fig. 3A, different concentrations of the drug had no significant cytotoxicity in the HepG2 cells after $12 \mathrm{~h}$ of treatment $(\mathrm{P}>0.05)$. After $24 \mathrm{~h}$ of drug treatment (Fig. 3B), the cell viability in HepG2 cells significantly decreased when HepG2 cells were treated with QS at a concentration of $4 \mathrm{mg} / \mathrm{mL}$ and SQE at a concentration of 2, $4 \mathrm{mg} / \mathrm{mL}(\mathrm{P}<0.01)$. However, QS with a concentration of $0.5 \mathrm{mg} / \mathrm{mL}$ increased the number of viable cells by more than $5 \%$, indicating that the low concentration of the QS was beneficial to the survival of HepG2 cells. At higher concentrations, the drug could decrease cell viability of normal HepG2 cells in a dose-dependent manner after $24 \mathrm{~h}$ treatment. 
Insulin resistance is a cardinal feature of T2DM, and therefore, an important therapeutic goal is to ameliorate insulin sensitivity (Ali et al. 2019). The HepG2 cells were preferentially considered for the establishment of the IR model due to the reduced glucose consumption in cells (Huang et al. 2015). The IR-HepG2 cells model was established in this study and the cytotoxicity of QS and SQE with concentrations of less than $2 \mathrm{mg} / \mathrm{mL}$ ( 0.25 to $1.5 \mathrm{mg} / \mathrm{mL})$ on IR-HepG2 cells was evaluated based on the above experimental results. As shown in Fig. 3C, the IR HepG2 cells treated with QS and SQE at different concentration had no significant difference on cell viability after $12 \mathrm{~h}$ incubation $(\mathrm{P}>0.05)$. After continuing to incubate for $12 \mathrm{~h}$ (Fig. 3D), the SQ concentration of 1 and $1.5 \mathrm{mg} / \mathrm{mL}$ significantly reduced the cell viability $(\mathrm{P}<0.05$ ), while the 0.25 and $0.5 \mathrm{mg} / \mathrm{mL}$ concentration increased the cell viability by more than $2 \%$. Different concentrations of SQE had no significant difference on the viability of IR HepG2 cells after $24 \mathrm{~h}$ treatment. The results shown that the SQ $(0.25$ to $0.5 \mathrm{mg} / \mathrm{mL})$ and SQE $(0.25$ to $1.5 \mathrm{mg} / \mathrm{mL})$ could be used to treat IR HepG2 cells without cytotoxicity.
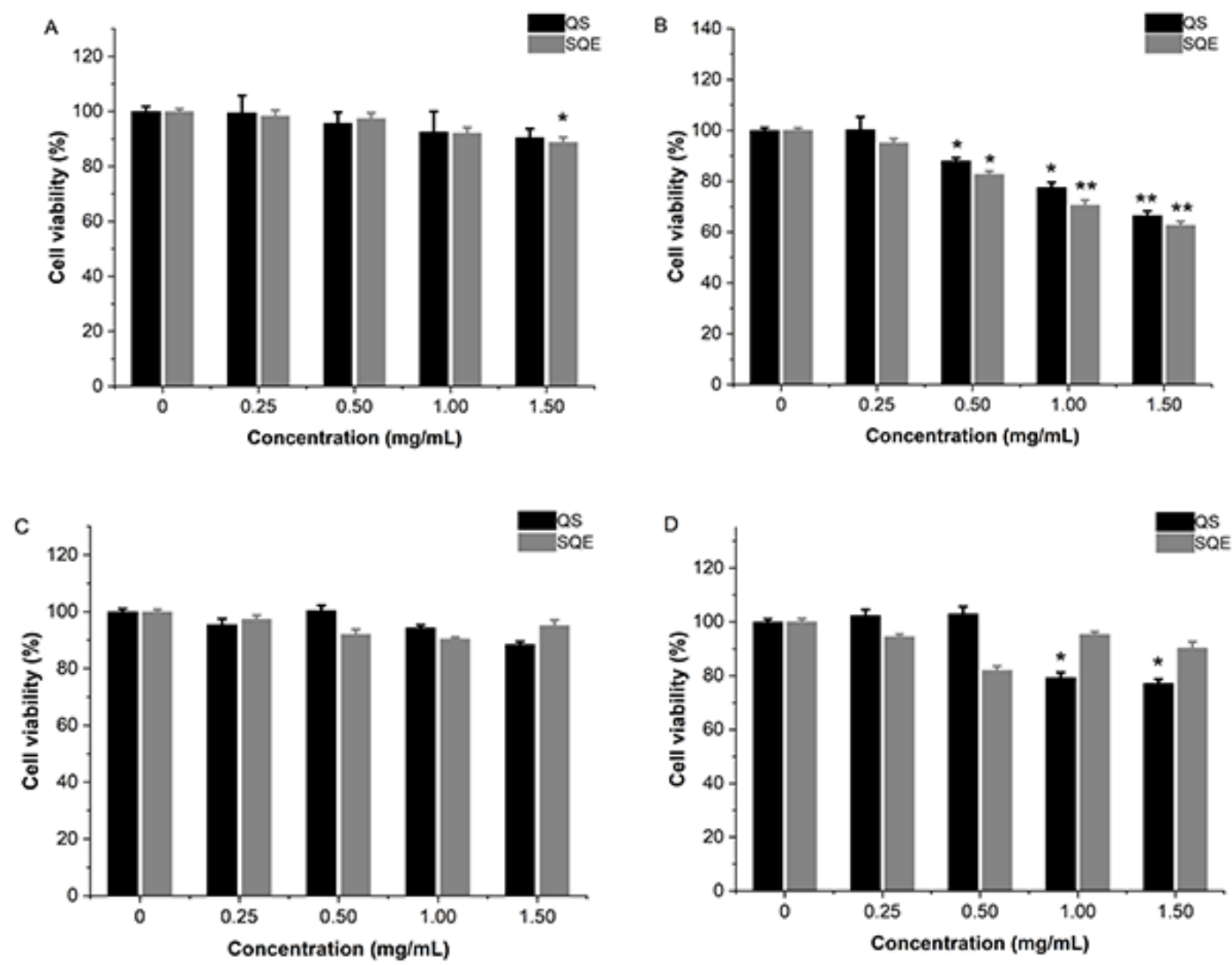

Fig. 3. Influence of samples on cell viability in HepG2 cells: (A) Cell viability of normal HepG2 cells for $12 \mathrm{~h}$; (B) Cell viability of normal HepG2 cells for $24 \mathrm{~h}$; (C) Cell viability of IR HepG2 cells for 12 h; (D) Cell viability of IR HepG2 cells for $24 \mathrm{~h}$; Values were expressed as the mean \pm S.D; $n=3$ for each group, ${ }^{*} \mathrm{P}<0.05,{ }^{* *} \mathrm{P}<0.01$ compared with the normal HepG2 cells

\section{Effect of L-Quebrachitol on Glucose Consumption in IR HepG2 Cells}

The concentrations between 0.25 and $1.5 \mathrm{mg} / \mathrm{mL}$ of QS and SQE were used to investigate whether L-quebrachitol might regulate glucose transport in IR HepG2 cells. As shown in Fig. 4, the glucose content in IR cells was the highest, indicating the glucose consumption in IR cells was decreased compared with the control cells and the success of 
the model. After treatment with drugs for $12 \mathrm{~h}$ (Fig. 4A), glucose consumption was remarkably increased after treating with $0.25,0.5 \mathrm{mg} / \mathrm{mL}$ of QS and $1.5 \mathrm{mg} / \mathrm{mL}$ of SQE compared with the IR cells $(\mathrm{P}<0.01)$. After $24 \mathrm{~h}$ of treatment (Fig. 4B), the QS and SQE in different concentration significantly enhanced insulin-stimulated glucose consumption by IR HepG2 cells comparing to that of the IR cells $(\mathrm{P}<0.05, \mathrm{P}<0.01)$. Over time, the effects of different concentrations of the drugs on promoting glucose consumption were enhanced, and the results also indicated that SQ was better than SQE at the same concentration and the same treatment time. In addition, after a sufficient period of time, a dose-effect relationship was expressed for SQE in promoting glucose consumption by IR HepG2 cells without affecting cell viability, while this phenomenon wasn't observed for QS. The $0.1 \mathrm{mg} / \mathrm{mL}$ RSG was also able to increase glucose uptake compared with the IR cells.
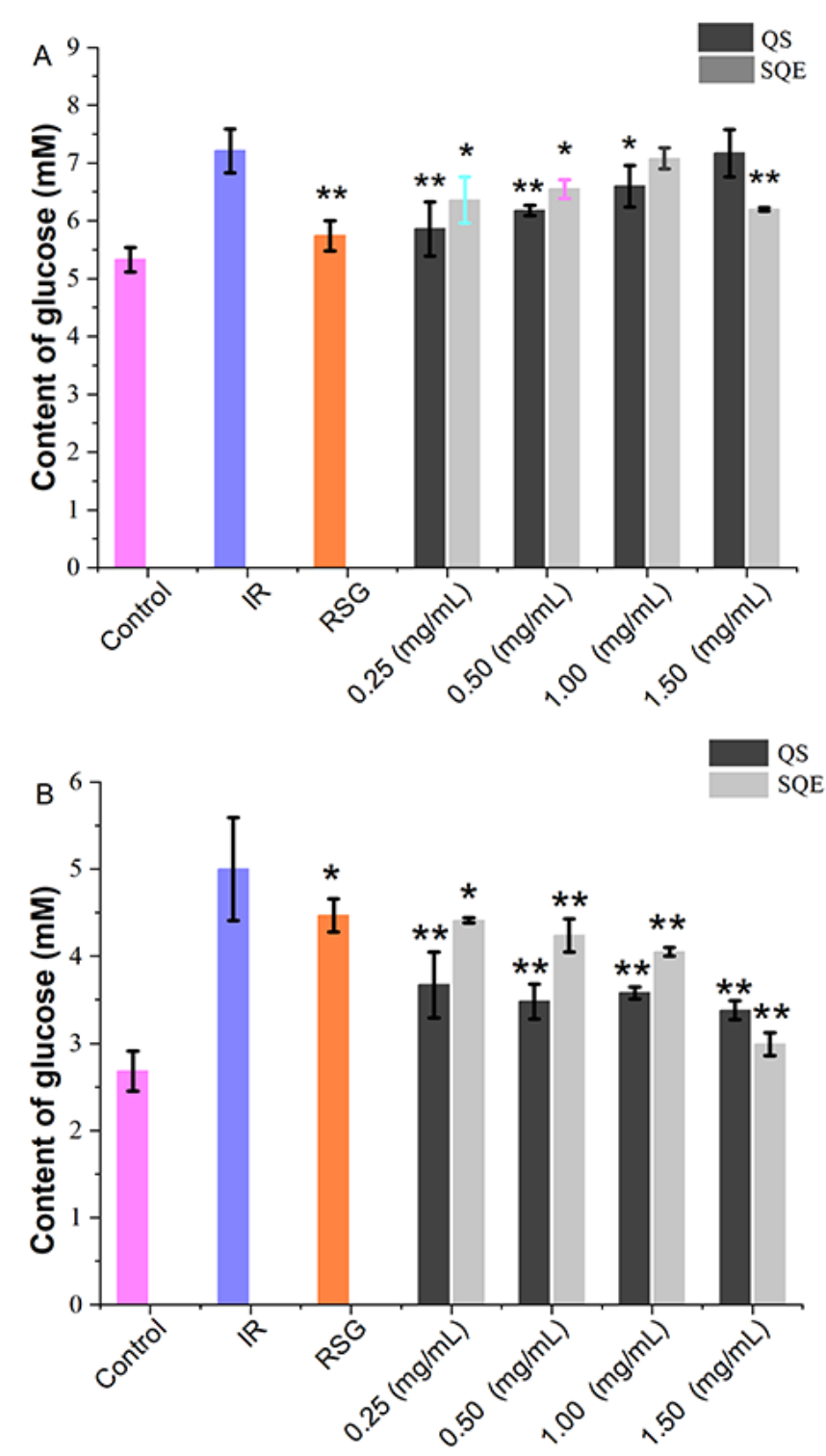

Fig. 4. Effect of samples on glucose consumption in IR HepG2 cells: (A) Effect of samples on glucose consumption for $12 \mathrm{~h}$; (B) Effect of baicalein on glucose consumption for $24 \mathrm{~h}$; Values were expressed as the mean \pm S.D. $n=3$ for each group; ${ }^{*} P<0.05,{ }^{*} P<0.01$ compared with the IR model group 
Insulin resistance can decrease glucose consumption due to the decreased sensitivity and reactivity of target tissues to insulin in maintaining the balance and stability of body's glucose level (Andersson et al. 2019). Sustained hyperglycemia is a major contributor to insulin resistance, which is one kind of prototypical properties of T2DM (Cordero-Herrera et al. 2014). Previous publications have documented that monomethyl ether derivatives of inositol exhibited physiological activity in improving hyperglycemia. Gao et al. (2015) for example, had reported that D-pinitol plays a positive role in regulating insulin mediated glucose uptake in in type 2 diabetes mellitus rats' liver. Shen et al. (2012) found that sequoyitol increases the ability of insulin to suppress glucose production in primary hepatocytes and to stimulate glucose uptake into primary adipocytes. In this experiment the authors firstly determined L-quebrachitol and the L-quebrachitol extract of sea buckthorn leaf exhibited hypoglycemic activity in vitro in their safe concentration. The results expanded the research scope of the biological activity of inositol derivatives.

\section{Effects of L-Quebrachitol on Lipid Metabolism in IR HepG2 Cells}

Type 2 diabetes mellitus is often accompanied by lipid metabolism disorders, and abnormal lipid metabolism further exacerbates the glucose metabolism disorder, which is a causal relationship (Jing et al. 2018).
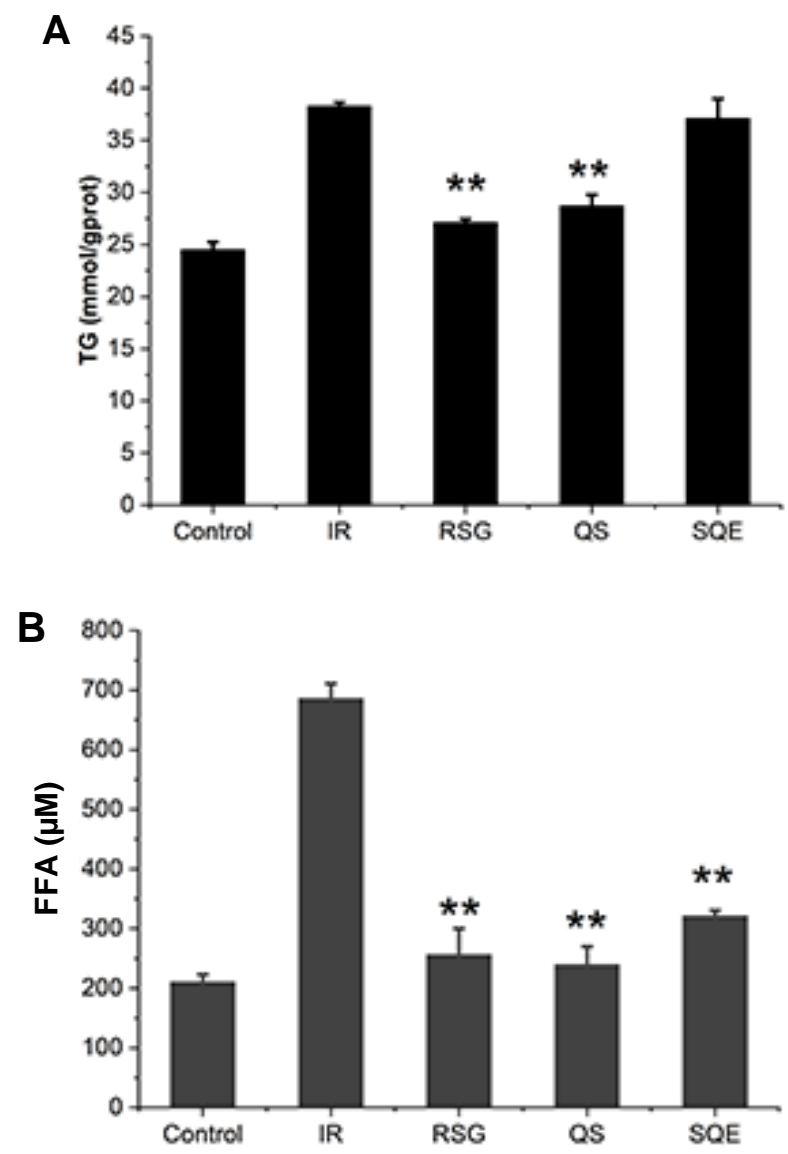

Fig. 5. Effect of samples on inhibitory effects of $(A)$ triglycerides and $(B)$ non-esterified fatty acid in IR HepG2 cells. Values were expressed as the mean \pm S.D. $n=3$ for each group. ${ }^{* *} P<0.01$ compared with the IR model group. 
Hepatocytes also play an important role in regulating lipid metabolic homeostasis and IR is also a common pathophysiological basis in patients with hyperlipidemia (Jing et al. 2018). Therefore, this study further investigated the effects of L-quebrachitol on lipid metabolism in IR HepG2 cells by evaluating the levels of TG and NEFA. As shown in Fig. 5, the QS treatment markedly decreased the TG and NEFA levels $(\mathrm{P}<0.01)$, and the SQE treatment significantly decreased the NEFA level $(\mathrm{P}<0.01)$. The TG in SQE group were decreased a little compared with the control group. The efficacy of QS in decreasing TG levels was a little weaker than that of RSG, while the efficacy of QS in decreasing NEFA levels was better than that of RSG and SQE. The results indicated that QS and SQE could inhibit TG and NEFA levels in IR-HepG2 cells.

\section{Effect of L-Quebrachitol on the Expression of G6Pase and PPAR in IR HepG2 Cells}

Glucose-6-phosphatase (G6Pase) is a key enzyme in regulation of hepatic gluconeogenesis. It is activated in glucose 6-phosphate metabolism as a rate limiting enzyme to produce glucose (Zhao et al. 2018), so it plays an important role in regulating the increased blood glucose levels. As shown in Fig. 6A-B, compared with the control group, QS and SQE effectively inhibited the expression levels of G6Pase in IR-HepG2 cells.


Fig. 6. Effect of samples on the expression of G6pase and PPARa in IR HepG2 cells:

(A) Expression strips of G6pase protein; (B) Level of G6pase protein; (C) Expression strips of PPARa protein; (D) Level of PPAR $\alpha$ protein; Values were expressed as the mean \pm S.D. $n=3$ for each group; ${ }^{*} P<0.05,{ }^{* *} P<0.01$ compared with the IR model group 
The intervention of QS $(1 \mathrm{mg} / \mathrm{mL})$ resulted in $79.9 \%(\mathrm{p}<0.01)$ decline of G6pase expression, and the intervention of SQE $(1 \mathrm{mg} / \mathrm{mL})$ led to $78.4 \%(\mathrm{p}<0.01)$ fall of G6pase expression as compared to IR model group. The AKT and AMPK are known to suppress gluconeogenesis in the liver (Mihaylova and Shaw 2011), and both AKT and AMPK phosphorylate GSK3b modulate gluconeogenesis, in which the expression G6Pase is suppressed (Cordero-Herrera et al. 2014). In this study, the expression of G6Pase was significantly increased in the IR cells but could be significantly reduced after QS and SQE treatments.

The PPARa is one of the fatty acid regulated nuclear hormone receptors that control lipid oxidation and expression of fatty acid transport proteins (Cao et al. 2019). As shown in Fig. 6C-D, QS and SQE significantly increased expression of PPAR $\alpha(P<0.05)$ and QS $(6.5 \%$ increment with $1 \mathrm{mg} / \mathrm{mL} \mathrm{QS})$ was superior to SQE $(15.1 \%$ increment with $1 \mathrm{mg} / \mathrm{mL}$ SQE). Activated AMPK affects the expression of the PPARa and then inhibits the synthesis of fatty acids, TG and promotes fatty acids uptake (Kahn et al. 2005; Kim et al. 2009). This may be an important part in improving the liver fat metabolism of L-quebrachitol.

\section{CONCLUSIONS}

1. The study investigated the chemical composition of sea buckthorn leaf L-quebrachitol extract (SQE) through two-dimensional gas chromatography in series with time-offlight mass spectrometry (GC×GC-TOF/MS). Seven compounds were identified in SQE besides L-quebrachitol.

2. The L-quebrachitol standard (QS) and SQE exhibited good inhibitory activity on $\alpha-$ amylase; and their type of enzyme inhibition was competitive inhibition in each case. Both QS and SQE could promote glucose consumption and regulate lipid metabolic on IR HepG2 cells in vitro within the appropriate dosage range.

3. The QS and SQE effectively inhibited the expressions levels of G6Pase and up regulation the expression of PPAR $\alpha$. These findings indicated that the prevention and treatment of diabetes may involve the regulation of related links and signaling pathways in liver glucose and lipid metabolism.

\section{ACKNOWLEDGMENTS}

This work was supported by Ministry of Water Resources and Soil Conservation Plant Development and Management Center (grant number: 2020HXKFSWXY001). The authors are grateful to Professor Lv Zhaolin of Beijing Forestry University.

\section{Author Contributions}

$\mathrm{Mu}$ Yihan: Analyzed data, interpreted the results and drafted, revised the manuscript. Cui Tao: Carried out experiments and collected test data. Yuan Weiqiong: Analyzed data. Lv ZhaoLin: Designed the study and supervised the research group. 


\section{REFERENCES CITED}

Ali, M. Y., Zaib, S., Rahman, M. M., Jannat, S., Iqbal, J., Park, S. K., and Chang, M. S. (2019). "Didymin, a dietary citrus flavonoid exhibits anti-diabetic complications and promotes glucose uptake through the activation of PI3K/Akt signaling pathway in insulin-resistant HepG2 cells," Chem. Biol. Interact. 305, 180-194. DOI: 10.1016/j.cbi.2019.03.018

Andersson, D. P., Dahlman, I., Eriksson Hogling, D., Bäckdahl, J., Toft, E., Qvisth, V., and Arner, P. (2019). "Improved metabolism and body composition beyond normal levels following gastric bypass surgery: A longitudinal study,” J. Intern. Med. 285(1), 92-101. DOI: 10.1111/joim.12824

Aravinthan, A., Challis, B. G., Shannon, N., Hoare, M., Heaney, J., and Alexander, G. J. (2015). "Selective insulin resistance in hepatocyte senescence," Exp. Cell Res.

331(1), 38-45. DOI: 10.1016/j.yexcr.2014.09.025

Ayyash, M., Al-Nuaimi, A. K., Al-Mahadin, S., and Liu, S. Q. (2018). "In vitro investigation of anticancer and ACE-inhibiting activity, $\alpha$-amylase and $\alpha$-glucosidase inhibition, and antioxidant activity of camel milk fermented with camel milk probiotic: A comparative study with fermented bovine milk," Food Chem. 239, 588597. DOI: 10.1016/j.foodchem.2017.06.149

Bechmann, L. P., Hannivoort, R. A., Gerken, G., Hotamisligil, G. S., Trauner, M., and Canbay, A. (2012). "The interaction of hepatic lipid and glucose metabolism in liver diseases," J. Hepatol. 56(4), 952-964. DOI: 10.1016/j.jhep.2011.08.025

Cao, C., Li, C., Chen, Q., Huang, Q., Pérez, M. E. M., and Fu, X. (2019). "Physicochemical characterization, potential antioxidant and hypoglycemic activity of polysaccharide from sargassum pallidum," Int. J. Biol. Macromol. 139, 1009-1017. DOI: 10.1016/j.ijbiomac.2019.08.069

Cao, X., Wu, C., Tian, Y., and Guo, P. (2019). "The caffeic acid moiety plays an essential role in attenuating lipid accumulation by chlorogenic acid and its analogues," RSC Adv. 9(22), 12247-12254. DOI: 10.1039/c8ra09395d

Chen, L., Lin, X., and Teng, H. (2019). "Emulsions loaded with dihydromyricetin enhance its transport through Caco-2 monolayer and improve anti-diabetic effect in insulin resistant HepG2 cell," J. Funct. Food. ArticleID:103672. DOI: 10.1016/j.jff.2019.103672

Cordero-Herrera, I., Martin, M. A., Goya, L., and Ramos, S. (2014). "Cocoa flavonoids attenuate high glucose-induced insulin signalling blockade and modulate glucose uptake and production in human HepG2 cells," Food Chem. Toxicol. 64, 10-19. DOI: 10.1016/j.fct.2013.11.014

De Olinda, T. M., Lemos, T. L. G., Machado, L. L., Rao, V. S., and Santos, F. A. (2008). "Quebrachitol-induced gastroprotection against acute gastric lesions: Role of prostaglandins, nitric oxide and K+ATP channels," Phytomedicine 15(5), 327-333. DOI: 10.1016/j.phymed.2007.09.002

Dixon, M. (1953). "The determination of enzyme inhibitor constants," Biochem. J. 55, $170-171$.

Gao, Y., Zhang, M., Wu, T., Xu, M., Cai, H., and Zhang, Z. (2015). "Effects of D-pinitol on insulin resistance through the PI3K/Akt signaling pathway in type 2 diabetes mellitus rats," J. Agric. Food Chem. 63(26), 6019-6026. DOI: 10.1021/acs.jafc.5b01238

Hu X., Tian A., Liu T., Zhou L., Bei W., and Guo J. (2019a). "Hesperidin ameliorates 
insulin resistance by regulating the IRS1-GLUT2 pathway via TLR4 in HepG2 cells," Phytother. Res. 33(6): 1697-1705. DOI: 10.1002/ptr.6358

Hu, S., Fan, X., Qi, P., and Zhang, X. (2019b). "Identification of anti-diabetes peptides from Spirulina platensis," J. Funct. Food. 56:333-341. DOI: 10.1016/j.jff.2019.03.024

Huang, Q., Chen, L., Teng, H., Song, H., Wu, X., and Xu, M. (2015). "Phenolic compounds ameliorate the glucose uptake in HepG2 cells' insulin resistance via activating AMPK: Anti-diabetic effect of phenolic compounds in HepG2 cells," $J$. Funct. Food. 19, 487-494. DOI: 10.1016/j.jff.2015.09.020

Jing, Y., Sun, Q., Xiong, X., Meng, R., Tang, S., Cao, S., Bi, Y., Zhu D. (2018). "Hepatocyte growth factor alleviates hepatic insulin resistance and lipid accumulation in high-fat diet-fed mice," J. Diabetes Investig. 10(2), 251-260. DOI: 10.1111/jdi.12904

Kahn, B. B., Alquier, T., Carling, D., and Hardie, D. G. (2005). “AMP-activated protein kinase: Ancient energy gauge provides clues to modern understanding of metabolism," Cell Metab. 1(1), 15-25. DOI: 10.1016/j.cmet.2004.12.003

Khan, B. A., Akhtar, N., and Mahmood, T. (2010). "A comprehensive review of a magic plant, hippophae rhamnoides," Pharmacognosy Journal, 2(16), 65-68. DOI: 10.1016/s0975-3575(10)80053-7

Kim, D. Y., Yuan, H. D., Chung, I. K., and Chung, S. H. (2009). "Compound K, intestinal metabolite of ginsenoside, attenuates hepatic lipid accumulation via AMPK activation in human hepatoma cells," J. Agric. Food Chem. 57(4), 1532-1537. DOI: 10.1021/jf802867b

Kwon, Y. I., Apostolidis, E., and Shetty, K. (2008). "Inhibitory potential of wine and tea against -amylase and-glucosidase for management of hyperglycemia linked to type 2 diabetes," J. Food Biochem. 32(1), 15-31. DOI: 10.1111/j.1745-4514.2007.00165.x

Larner, J., Brautigan, D. L., and Thorner, M. O. (2010). "D-chiro-inositol glycans in insulin signaling and insulin resistance," Mol. Med. 16(11-12), 543-552. DOI: 10.2119/molmed.2010.00107

Lineweaver, H., and Burk, D. (1934). "The determination of enzyme dissociation constants," J. Am. Chem. Soc. 56, 658-666.

Lo Piparo, E., Scheib, H., Frei, N., Williamson, G., Grigorov, M., and Chou, C. J. (2008). "Flavonoids for controlling starch digestion: Structural requirements for inhibiting human alpha-amylase," J. Med. Chem. 51, 3555-3561. DOI: 10.1021/jm800115x

McCance, R. A., and Lawrence, R. D. (1933). "An investigation of quebrachitol as a sweetening agent for diabetics," The Biochemical Journal. 27, 986-989.

Michell, R. H. (2008). "Inositol derivatives: Evolution and functions," Nat. Rev. Mol. Cell Biol. 9(2), 151-161. DOI: 10.1038/nrm2334

Mihaylova, M. M., and Shaw, R. J. (2011). "The AMPK signalling pathway coordinates cell growth, autophagy and metabolism," Nat. Cell Biol. 13(9), 1016-1023. DOI: $10.1038 / \mathrm{ncb} 2329$

Shen, H., Shao, M., Cho, K. W., Wang, S., Chen, Z., Sheng, L., Wang, T., Liu, Y., and Rui, L. (2012). "Herbal constituent sequoyitol improves hyperglycemia and glucose intolerance by targeting hepatocytes, adipocytes, and $\beta$-cells," Am. J. Physiol.: Endocrinol. Metab. 302(8), 932-940. DOI: 10.1152/ajpendo.00479.2011

Sleight, S., Wilson, B., Heimark, D., and Larner, J. (2002). "Gq/11 is involved in insulinstimulated inositol phosphoglycan putative mediator generation in rat liver membranes: co-localization of $\mathrm{Gq} / 11$ with the insulin receptor in membrane 
vesicles," Biochem. Biophys. Res. Commun. 295(2), 561-569. DOI: 10.1016/s0006$291 \mathrm{x}(02) 00701-5$

Tao, C., Wang, J., Yao, Y., Han, X., and Lv, Z. (2019). "Characterization and distribution rule of quebrachitol in Hippophae rhamnoides L," Journal of Beijing Forestry University. 42(01), 121-126.

Wang, Y. M., Pan, X., He, Y., Chi, C. F., and Wang, B. (2020). "Hypolipidemic activities of two pentapeptides (VIAPW and IRWWW) from miiuy croaker (Miichthys miiuy) muscle on lipid accumulation in HepG2 cells through regulation of AMPK pathway," Appl. Sci. 10(3), 817. DOI: 10.3390/app10030817

Wu, Y., Yuan, W., Han, X., Hu, J., Yin, L., and Lv, Z. (2020). "Integrated analysis of fatty acid, sterol and tocopherol components of seed oils obtained from four varieties of industrial and environmental protection crops," Ind. Crop. Prod. 154, 112655. DOI: $10.1016 /$ j.indcrop.2020.11265

Xue, Y., Miao, Q., Zhao, A., Zheng, Y., Zhang, Y., Wang, P., Heikki, K., and Yang, B. (2015). "Effects of sea buckthorn (Hippophaë rhamnoides) juice and L-quebrachitol on type 2 diabetes mellitus in db/db mice," J. Funct. Food. 16, 223-233. DOI: 10.1016/j.jff.2015.04.041

Yang, L., Wen, K. S., Ruan, X., Zhao, Y. X., Wei, F., and Wang, Q. (2018). "Response of plant secondary metabolites to environmental factors," Molecules. 23(4), 762. DOI: 10.3390/molecules23040762

Yao, Y., Liu, K., Zhao, Y., Hu, X., and Wang, M. (2018). "Pterostilbene and 4'methoxy-resveratrol inhibited lipopolysaccharide-induced inflammatory response in RAW264.7 macrophages," Molecules. 23(5), 1148. DOI: $10.3390 /$ molecules 23051148

Zhao, F., Wang, H., Wei, P., Jiang, G., Wang, W., Zhang, X., and Ru, S. (2018). "Impairment of bisphenol F on the glucose metabolism of zebrafish larvae," Ecotox. Environ. Safe. 165, 386-392. DOI: 10.1016/j.ecoenv.2018.09.017

Zielinska, A., and Nowak, I. (2017). "Abundance of active ingredients in sea-buckthorn oil,” Lipids Health Dis. 16(1), 95-105. DOI: 10.1186/s12944-017-0469-7

Article submitted: October 9, 2021; Peer review completed: November 14, 2021; Revised version received and accepted: November 21, 2021; Published: November 29, 2021. DOI: 10.15376/biores.17.1.527-542 